\title{
Mathematical Mortality Models and Modeling Urbanization's Influence on Deaths in Jamaica
}

Paul Andrew Bourne ${ }^{1 *}$, Angela Hudson-Davis², Charlene Sharpe-Pryce ${ }^{3}$, Jeffery Clarke ${ }^{4}$, Ikhalfani Solan ${ }^{5}$, Joan Rhule ${ }^{4}$, Cynthia Francis $^{5}$, Olive Watson-Coleman ${ }^{6}$, Anushree Sharma ${ }^{7}$ and Janinne Campbell-Smith ${ }^{8}$

${ }^{1}$ Socio-Medical Research Institute, Jamaica

${ }^{2}$ Capella University, USA

${ }^{3}$ Department of History, Northern Caribbean University, Mandeville, Jamaica

${ }^{4}$ University of Technology, Jamaica

${ }^{5}$ Department of Mathematics and Computer Science, South Carolina State University, USA

${ }^{6}$ Southern Connecticut State University, USA

${ }^{7}$ IIS University, Jaipur, India

${ }^{8}$ Cable and Wireless Company Limited, Jamaica

\begin{abstract}
Background: Inspite of the body of knowledge which exists on mortality, the literature is void of a study on 'Time-specific Mortality'.
\end{abstract}

Objectives: This study aims to evaluate 'Time-specific Mortality' in Jamaica, the role of urbanization, and sexratio on mortality.

Materials and method: The data were derived from various Jamaica Government Publications including The Economic and Social Survey of Jamaica; 2011 Census of Population and Housing report for Jamaica and the Demographic Statistics, and the Statistical Department of the Jamaica Constabulary Force. Data were recorded, stored and retrived using the Statistical Packages for the Social Sciences for Windows, Version 21.0, as well as Microsoft Excel. The level of significance that is used to determine statistical significance is less than $5 \%(0.05)$.

Results: The annual probability of mortality in Jamaica, for the studied period is $0.005 \leq p x \leq 0.008$. The probability of dying in Kingston and Saint Andrew is generally greater than that of Jamaica, which is equally the case in Saint James (i.e., $0.005 \leq p x \leq 0.008$ ), Manchester (i.e., $0.006 \leq p x \leq 0.008$ ), with the probability of dying being the least in Hanover $(0.003 \leq \mathrm{px} \leq 0.005)$. The majority of deaths occurred in January $(9.8 \%)$, with the least being in December (7.8\%). Although on average the least number of deaths occurred in December $2011(7.8 \%), 11 \%$ of Jamaicans died in December compared to $8 \%$ in Feburary and $9 \%$ in August as well as April-to-June. Urbanization and the sex-ratio explain $88 \%$ of the variability in mortality in Jamaica, with urbanization explaining $79.9 \%$ of the variability and the sex-ratio contributing the remaining $8.1 \%$.

Conclusion: The results presented in this study speaks to the dominance of urbanization in the mortality discourse, urbanization's role in reducing life expectancy and that the time as well as the sex-ratio, which offers some insights into changes in mortality. These findings offer policy makers critical information that can be used to develop intervention programmes as well as provide scholars with new insights into the mortality discourse.

Keywords: Demography; Gerontology; Law of mortality; Mortality; Probability of death; Sex-ratio; Urbanization

\section{Introduction}

The study of human mortality is well researched in demography and this dates back to the seventeenth century when John Graunt sought to explain occurrence of deaths in London, England [1]. Mortality is the first constitutent of the study of demography and it contributes to many aspects of the discipline to include life expectancy, population parameters (i.e., growth rate, age structure), late-life mortality deceleration, health, stable population and life tables [2-6]. Outside of the established tenets of mortality (i.e., life expectancy, life tables, stable population, age structure, population projection and population growth rate), a Caribbean health demographer, Paul Andrew Bourne, along with other scholars have added an extensive body of literature on mortality to include and not limited to deaths at older ages $\left(75^{+}\right.$years), the economics of mortality at older ages, and mortality and health [710] as well as murder economics [11].

The study of mortality is a highly mathematical area, which explains it being studied by mathematicians, actuarists, and statisticians as well as demographers, with each contributing a part to the general mortality discourse $[2,3,12-16]$. Inspite of the body of knowledge which exists on mortality, the literature is void of a study on 'Time-specific Mortality.' Researchers and agencies like the World Health Organizations have been preoccupied, rightfully so, with non-communicable diseases (CNCDs) because they account for the majority of human deaths in the world [17-22] and no attention is placed on 'Time-specific Morality.' This study is proposing that 'Time-specific Mortality'covers the area of geographical and time mortality. The reality is, the mortality discourse is void of a study that examines whether deaths occur more at a particular time of the year or geographical locality. In addition, we also tested six hypotheses 1) mortality is influenced by urbanization

*Corresponding author: Bourne PA, Director, Socio-Medical Research Institute, Kingston, Jamaica, Tel: (1 876) 566-3088; E-mail: paulbourne1@yahoo.com

Received April 10, 2015; Accepted May 18, 2015; Published May 22, 2015

Citation: Bourne PA, Hudson-Davis A, Sharpe-Pryce C, Clarke J, Solan I, et al. (2015) Mathematical Mortality Models and Modeling Urbanization's Influence on Deaths in Jamaica. Arts Social Sci J 6: 102. doi:10.4172/2151-6200.1000102

Copyright: (c) 2015 Bourne PA, et al. This is an open-access article distributed under the terms of the Creative Commons Attribution License, which permits unrestricted use, distribution, and reproduction in any medium, provided the original author and source are credited. 
and the sex-ratio, 2) urbanization has a greater influence on mortality than the sex-ratio, 3) a direct correlation exists between urbanization and the sex-ratio (using data for 2011), 4) the probability of death for age is an exponential function, 5) the probability of death for age is the same slope over the lifecourse, and 6) the probability of death is the same slope over the lifecourse of the population.

\section{Theoretical framework}

The Gompertz-Makeham law of mortality described that death rate is a composite function of age-independent components (named after Makeham) and the age-dependent components (named after Gompertz) [2,3]. The Gompertz-Makeham law of mortality showed that death exponentially increases with age, using age from 30 to 80 years. It is expressed in the hazard function below (i.e., $\mathrm{h}(\mathrm{x})$ ):

$$
h(x)=\alpha e^{\beta x}+\lambda \text { where } \alpha>0, \beta>0, \lambda>0 \text { and } x \in \mathbb{R}^{+}
$$

This study employs the Gompertz-Makeham law of mortality to examine deaths in Jamaica, while expanding on the discourse to include urbanization, sex-ratio, area and time of death.

\section{Materials and Methods}

The current work is a secondary data analysis. The data were derived from various Jamaica Government Publications including The Economic and Social Survey of Jamaica (ESSJ) [23]; 2011 Census of Population \& Housing report for Jamaica [24]; the Demographic Statistics [25], and the Statistical Department of the Jamaica Constabulary Force (JCF) [26]. Demographic Statistics provide data on mortality, population, and deaths and the Statistical Department of the Jamaica Constabulary Force on murders. The Economic and Social Survey of Jamaica (ESSJ) is a publication which collates information on social and economic indicators of Jamaica. It is a publication by the Planning Institute of Jamaica. The period for this work is from 2000 to 2011. Data were recorded, stored and retrieved using the Statistical Packages for the Social Sciences for Windows, Version 21.0, as well as Microsoft Excel. The level of significance that is used to determine statistical significance is less than $5 \%(0.05)$. This study applies the computations of rates, proportion and probability. Ordinary least square (OLS) regression analyses are used to establish the model for mortality. We also tested six hypotheses 1) mortality is influenced by urbanization and the sex-ratio, 2) urbanization has a greater influence on mortality than the sex-ratio, 3 ) a direct correlation exists between urbanization and the sex-ratio (using data for 2011), 4) the probability of death for age is an exponential func tion, 5) the probability of death for age is the same slope over the lifecourse, and 6) the probability of death is the same slope over the lifecourse:

H 1 (i.e., null hypothesis one): Mortality in Jamaica $\neq f$ (Urbanization, Sex-ratio)

$\mathrm{H}_{\mathrm{o}} 2$ (i.e., null hypothesis two): Urbanization contributes less to mortality than the sex-ratio

$\mathrm{H}_{\mathrm{o}}$ 3: (i.e., null hypothesis three): A direct correlation exists between urbanization and the sex-ratio

$\mathrm{H}_{\mathrm{o}} 4$ (i.e., null hypothesis four): The probability of death for age is not an exponential function

$\mathrm{H}_{\mathrm{o}} 5$ (i.e., null hypothesis five): The probability of death for age is the same slope over the lifecourse

$\mathrm{H}_{\mathrm{o}} 6$ (i.e., null hypothesis six): Urbanization constantly increases the rate of death in geographical areas.

\section{Operational definitions}

Mortality rate (crude death rate): The total number of recorded deaths for a period 12-month (i.e., from January to December, $\mathrm{D}_{\mathrm{x}}$ ) divided by the mid-year population $\left(\mathrm{N}_{\mathrm{t}}\right)$ time 1,000 :

$$
\left(C D R=\frac{D x}{N t} \cdot 1000\right)
$$

Murder denotes the number of people unlawfully killed (a crime causing death without a lawful excuse) within a particular geopolitical zone (excluding police killings or homicides). Murder rate: The total number of people killed (excluding police killings) divided by the midyear population times 1,000 .

Age-specific death rate: Number of deaths in age interval $x$ to $x+n$ divided by mid-year population in age interval $\mathrm{x}$ to $\mathrm{x}+\mathrm{n}$ for time period

$$
\left(n M x=\frac{n D x}{n N x}\right) \text {. }
$$

Proportion of age in interval: Mid-year population in age interval $\mathrm{x}$ to $\mathrm{x}+\mathrm{n}$ divided by the mid-year population of the nation for the time period $\mathrm{t}$ :

$$
\left(n \mathbf{C} x=\frac{n \mathbf{N} x}{\mathbf{N}_{\mathbf{t}}}\right) .
$$

Daily murder: The total number of murder for each year divided by 365 .

Daily mortality: Total number of deaths divided by 365 .

Murder/mortality rate: The total number of murder for a year divided by total number of deaths for the corresponding year times 100 .

Proportion of deaths: The total number of deaths for a specific area divided by the total number of deaths for the nation in time period $i$.

Area-specific mortality: Total number of deaths for a specific area for time period i divided by the total number of deaths for the nation in time period $\mathrm{i}$.

Time-specific mortality: Total number of deaths for a specific time period i divided by the total number of deaths for the nation in time period $i$.

\section{Area-specific probability of mortality:}

$$
q_{x}=\frac{D_{x}}{K_{x}+\frac{1}{2} D_{x}},
$$

where $q_{x}$ area-specific probability of mortality (or deaths); $D_{x}$ is registered deaths in a specific area for period $\mathrm{x}$, and $\mathrm{K}_{\mathrm{x}}$ is estimated mid-year population for time perid $\mathrm{x}$.

\section{Age-specific probability of mortality:}

$$
q_{x}=\frac{D_{x}}{K_{x}+\frac{1}{2} D_{x}},
$$

where $\mathrm{q}_{\mathrm{x}}$ age-specific probability of mortality (or deaths); $\mathrm{D}_{\mathrm{x}}$ is registered deaths for the age interval $\mathrm{x}$, and $\mathrm{K}_{\mathrm{x}}$ is estimated mid-year population for the age cohort $\mathrm{x}$.

Probability of death:

$$
q_{x}=\frac{D_{x}}{K_{x}+\frac{1}{2} D_{x}},
$$


Citation: Bourne PA, Hudson-Davis A, Sharpe-Pryce C, Clarke J, Solan I, et al. (2015) Mathematical Mortality Models and Modeling Urbanization's Influence on Deaths in Jamaica. Arts Social Sci J 6: 102. doi:10.4172/2151-6200.1000102

Page 3 of 9

where $\mathrm{q}_{\mathrm{x}}$ probability of mortality (or deaths) in period $\mathrm{x} ; \mathrm{D}_{\mathrm{x}}$ is registered deaths for period $\mathrm{x}$, and $\mathrm{K}_{\mathrm{x}}$ is estimated mid-year population for time perid $\mathrm{x}$.

Probability of survival to age $x, p_{x}$ :

$$
p_{x}=1-q_{x}=1-\frac{D_{x}}{K_{x}+\frac{1}{2} D_{x}}
$$

where $\mathrm{p}_{\mathrm{x}}$ is the probability of survival to age in period $\mathrm{x}, \mathrm{q}_{\mathrm{x}}$ probability of mortality (or deaths) in period $\mathrm{x} ; \mathrm{D}_{\mathrm{x}}$ is registered deaths in period $\mathrm{x}$, and $\mathrm{K}_{\mathrm{x}}$ is estimated mid-year population for time perid $\mathrm{x}$.

Sex ratio: The total number of males in a particular geographical area for time period i divided by the total number of females in the same geographical area for time period i times 100. A value over 100 indicates more males per 100 females and vice versa (less males per 100 females): Sex ratio $=M_{i} / F_{i} \times 100$, where $M_{i}$ denotes the number of males in a geographical area for time period $i$ and $F_{i}$ means the total number of females in the corresponding geographical area for time period i.

Urbanization: A percentage of a geographically defined border that is urban-that is having a population of $2000+$ people, modern amenities and utilities.

\begin{tabular}{|c|c|c|c|c|c|c|c|c|c|}
\hline Year & Mortality & Murder & $\begin{array}{l}\text { Mid-year } \\
\text { Population }\end{array}$ & Murder rate & Mortality rate & Daily murder & Daily Mortality & $\begin{array}{c}\text { Murderl } \\
\text { Mortality rate } \\
\text { (in \%) }\end{array}$ & $\begin{array}{c}\text { Probability of } \\
\text { death }\end{array}$ \\
\hline 2000 & 15945 & 0887 & 2589400 & 34 & 616 & 2 & 44 & 6 & 0.006 \\
\hline 2001 & 16239 & 1191 & 2604100 & 46 & 624 & 3 & 44 & 7 & 0.006 \\
\hline 2002 & 14989 & 1045 & 2615200 & 40 & 573 & 3 & 41 & 7 & 0.006 \\
\hline 2003 & 14729 & 975 & 2625700 & 37 & 561 & 3 & 40 & 7 & 0.006 \\
\hline 2004 & 14513 & 1471 & 2638100 & 56 & 550 & 4 & 40 & 10 & 0.005 \\
\hline 2005 & 15065 & 1674 & 2650400 & 63 & 568 & 5 & 41 & 11 & 0.006 \\
\hline 2006 & 15321 & c1 340 & 2663100 & 50 & 575 & 4 & 42 & 9 & 0.006 \\
\hline 2007 & 16614 & 1574 & 2675800 & 59 & 621 & 4 & 46 & 9 & 0.006 \\
\hline 2008 & 16371 & 1601 & 2687200 & 60 & 609 & 4 & 45 & 10 & 0.006 \\
\hline 2009 & 17467 & 1680 & 2695600 & 62 & 648 & 5 & 48 & 10 & 0.006 \\
\hline 2010 & 21503 & 1428 & 2695543 & 53 & 798 & 4 & 59 & 7 & 0.008 \\
\hline 2011 & 16926 & c1 132 & 2699838 & 42 & 627 & 3 & 46 & 7 & 0.006 \\
\hline Average & 16306 & 1333 & 2653332 & 50 & 614 & 4 & 45 & 8 & 0.006 \\
\hline
\end{tabular}

Table 1: Mortality, Murder and rates of murder mortality, probability of mortality and murder expressed over mortality rate.

\begin{tabular}{|c|c|c|c|c|c|c|c|c|c|c|c|c|c|}
\hline Parish & 2000 & 2001 & 2002 & 2003 & 2004 & 2005 & 2006 & 2007 & 2008 & 2009 & 2010 & 2011 & $\begin{array}{l}\text { Proportion } \\
\text { of deaths }\end{array}$ \\
\hline $\begin{array}{l}\text { Kingston and St. } \\
\text { Andrew }\end{array}$ & 0.33 & 0.30 & 0.30 & 0.33 & 0.23 & 0.31 & 0.30 & 0.31 & 0.30 & 0.30 & 0.29 & 0.30 & 0.20 \\
\hline St. Thomas & 0.04 & 0.03 & 0.04 & 0.04 & 0.04 & 0.04 & 0.03 & 0.03 & 0.04 & 0.03 & 0.03 & 0.03 & 0.02 \\
\hline Portland & 0.03 & 0.03 & 0.03 & 0.03 & 0.04 & 0.03 & 0.03 & 0.03 & 0.02 & 0.03 & 0.02 & 0.03 & 0.02 \\
\hline St. Mary & 0.04 & 0.04 & 0.04 & 0.04 & 0.05 & 0.04 & 0.04 & 0.04 & 0.04 & 0.04 & 0.04 & 0.04 & 0.03 \\
\hline St. Ann & 0.07 & 0.07 & 0.07 & 0.06 & 0.06 & 0.07 & 0.07 & 0.06 & 0.06 & 0.07 & 0.06 & 0.07 & 0.04 \\
\hline Trelawny & 0.03 & 0.03 & 0.03 & 0.03 & 0.03 & 0.02 & 0.02 & 0.02 & 0.02 & 0.03 & 0.02 & 0.02 & 0.02 \\
\hline St. James & 0.09 & 0.08 & 0.08 & 0.07 & 0.07 & 0.08 & 0.09 & 0.08 & 0.08 & 0.09 & 0.08 & 0.09 & 0.05 \\
\hline Hanover & 0.02 & 0.02 & 0.02 & 0.02 & 0.03 & 0.02 & 0.02 & 0.02 & 0.02 & 0.02 & 0.02 & 0.02 & 0.01 \\
\hline Westmoreland & 0.05 & 0.06 & 0.06 & 0.05 & 0.05 & 0.05 & 0.05 & 0.05 & 0.06 & 0.05 & 0.05 & 0.05 & 0.03 \\
\hline St. Elizabeth & 0.05 & 0.06 & 0.05 & 0.05 & 0.06 & 0.05 & 0.05 & 0.06 & 0.06 & 0.06 & 0.05 & 0.05 & 0.04 \\
\hline Manchester & 0.08 & 0.08 & 0.10 & 0.10 & 0.08 & 0.10 & 0.10 & 0.09 & 0.10 & 0.09 & 0.09 & 0.09 & 0.06 \\
\hline Clarendon & 0.07 & 0.08 & 0.07 & 0.07 & 0.10 & 0.06 & 0.08 & 0.08 & 0.08 & 0.07 & 0.07 & 0.07 & 0.05 \\
\hline St. Catherine & 0.12 & 0.12 & 0.12 & 0.12 & 0.16 & 0.14 & 0.11 & 0.13 & 0.13 & 0.11 & 0.09 & 0.13 & 0.08 \\
\hline Unknown & 0.00 & 0.00 & 0.00 & 0.00 & 0.01 & 0.00 & 0.00 & 0.00 & 0.00 & 0.00 & 0.09 & 0.00 & 0.01 \\
\hline Total & 15945 & 16239 & 14989 & 14729 & 14050 & 15528 & 14645 & 15768 & 15539 & 13753 & 17107 & 16926 & 185218 \\
\hline Incidence rate & 8.61 & 8.77 & 8.09 & 7.95 & 7.59 & 8.38 & 7.91 & 8.51 & 8.39 & 7.43 & 9.24 & 9.14 & \\
\hline
\end{tabular}

Table 2: Area-specific Mortality Model.

Table 1 presents information on mortality, murder and rates of murder mortality, and murder expressed over mortality rate. The annual mortality rate in Jamaica lies between 550 per 100,000 and 798 per 100,000 for the period 2000 to 2011 with the murder rate per 100,000 being between 34 and 63. Overall, on average 4 Jamaicans are murdered daily over the studied period and the average murder as a percentage of mortality for the 13 years is 8 , with the rate being the highest in 2005 (11\%). Furthermore, for the studied period, the mean number of Jamaicans that die daily is 45 , of which four are murdered.

Table 2 presents the Area-specific Mortality Model. Over the 12 years (2000-2011), there were 185, 218 reported deaths in Jamaica. Of the total number of reported deaths, $20 \%$ of those were in Kingston and Saint Andrew (i.e., 1 in every 5 deaths), 8\% in Saint Catherine, $6 \%$ in Manchester, $5 \%$ in Clarendon as well as St. James, with the least being in Hanover (1\%). Most of the deaths occurred in 2010 (9.24\%) followed by 2011 (9.14\%), with least death occurring in 2009 (7.43\%). On disaggregating the overall proportion of deaths for the 12-year period, deaths in Kingston and Saint Andrew reads: $0.23 \leq$ deaths $\leq$ 0.33 .

Table 3 shows the proportion of annual deaths by time of year from 2000 to 2011 including the total proportion of deaths for each time 
Citation: Bourne PA, Hudson-Davis A, Sharpe-Pryce C, Clarke J, Solan I, et al. (2015) Mathematical Mortality Models and Modeling Urbanization's Influence on Deaths in Jamaica. Arts Social Sci J 6: 102. doi:10.4172/2151-6200.1000102

Page 4 of 9

\begin{tabular}{|c|c|c|c|c|c|c|c|c|c|c|c|c|c|}
\hline Details & 2000 & 2001 & 2002 & 2003 & 2004 & 2005 & 2006 & 2007 & 2008 & 2009 & 2010 & 2011 & Total \\
\hline January & 0.10 & 0.10 & 0.10 & 0.10 & 0.10 & 0.08 & 0.09 & 0.11 & 0.10 & 0.11 & 0.10 & 0.12 & 0.098 \\
\hline February & 0.09 & 0.07 & 0.08 & 0.08 & 0.08 & 0.07 & 0.08 & 0.07 & 0.09 & 0.09 & 0.08 & 0.10 & 0.080 \\
\hline March & 0.09 & 0.09 & 0.08 & 0.09 & 0.09 & 0.08 & 0.08 & 0.06 & 0.09 & 0.10 & 0.11 & 0.11 & 0.086 \\
\hline April & 0.09 & 0.08 & 0.09 & 0.08 & 0.09 & 0.08 & 0.08 & 0.09 & 0.09 & 0.10 & 0.09 & 0.09 & 0.084 \\
\hline May & 0.09 & 0.08 & 0.08 & 0.08 & 0.08 & 0.09 & 0.10 & 0.08 & 0.09 & 0.08 & 0.09 & 0.10 & 0.083 \\
\hline June & 0.09 & 0.09 & 0.08 & 0.08 & 0.09 & 0.08 & 0.09 & 0.08 & 0.08 & 0.09 & 0.09 & 0.10 & 0.084 \\
\hline July & 0.09 & 0.09 & 0.09 & 0.09 & 0.08 & 0.08 & 0.08 & 0.09 & 0.09 & 0.08 & 0.10 & 0.09 & 0.083 \\
\hline August & 0.08 & 0.09 & 0.08 & 0.07 & 0.08 & 0.08 & 0.09 & 0.08 & 0.06 & 0.07 & 0.09 & 0.10 & 0.079 \\
\hline September & 0.08 & 0.07 & 0.07 & 0.08 & 0.08 & 0.10 & 0.08 & 0.08 & 0.07 & 0.07 & 0.10 & 0.09 & 0.081 \\
\hline October & 0.08 & 0.09 & 0.09 & 0.08 & 0.08 & 0.08 & 0.09 & 0.09 & 0.08 & 0.07 & 0.10 & 0.09 & 0.080 \\
\hline November & 0.07 & 0.07 & 0.08 & 0.07 & 0.08 & 0.11 & 0.09 & 0.09 & 0.06 & 0.07 & 0.11 & 0.10 & 0.084 \\
\hline December & 0.05 & 0.08 & 0.08 & 0.09 & 0.07 & 0.07 & 0.08 & 0.08 & 0.09 & 0.07 & 0.11 & 0.08 & 0.078 \\
\hline Total & 15945 & 16239 & 14989 & 14729 & 14050 & 15528 & 14645 & 15768 & 15539 & 13753 & 17107 & 16926 & 185218 \\
\hline
\end{tabular}

Table 3: Time-specific Mortality Model.

\begin{tabular}{|c|c|c|c|c|c|c|c|c|c|c|c|c|c|}
\hline \multirow[t]{2}{*}{ Details } & & January & February & March & April & May & June & July & August & September & October & November & December \\
\hline & $\mathrm{PA}_{\mathrm{a}}$ & $\mathrm{PT}_{\mathrm{i}}=0.098$ & 0.08 & 0.086 & 0.084 & 0.083 & 0.084 & 0.083 & 0.079 & 0.081 & 0.08 & 0.084 & 0.078 \\
\hline $\begin{array}{l}\text { Kingston and } \\
\text { St. Andrew }\end{array}$ & 0.20 & 1.960 & 1.60 & 1.720 & 1.680 & 1.660 & 1.680 & 1.660 & 1.580 & 1.620 & 1.60 & 1.680 & 1.560 \\
\hline St. Thomas & 0.02 & 0.196 & 0.16 & 0.172 & 0.168 & 0.166 & 0.168 & 0.166 & 0.158 & 0.162 & 0.16 & 0.168 & 0.156 \\
\hline Portland & 0.02 & 0.196 & 0.16 & 0.172 & 0.168 & 0.166 & 0.168 & 0.166 & 0.158 & 0.162 & 0.16 & 0.168 & 0.156 \\
\hline St. Mary & 0.03 & 0.294 & 0.24 & 0.258 & 0.252 & 0.249 & 0.252 & 0.249 & 0.237 & 0.243 & 0.24 & 0.252 & 0.234 \\
\hline St. Ann & 0.04 & 0.392 & 0.32 & 0.344 & 0.336 & 0.332 & 0.336 & 0.332 & 0.316 & 0.324 & 0.32 & 0.336 & 0.312 \\
\hline Trelawny & 0.02 & 0.196 & 0.16 & 0.172 & 0.168 & 0.166 & 0.168 & 0.166 & 0.158 & 0.162 & 0.16 & 0.168 & 0.156 \\
\hline St. James & 0.05 & 0.490 & 0.40 & 0.430 & 0.420 & 0.415 & 0.420 & 0.415 & 0.395 & 0.405 & 0.40 & 0.420 & 0.390 \\
\hline Hanover & 0.01 & 0.098 & 0.08 & 0.086 & 0.084 & 0.083 & 0.084 & 0.083 & 0.079 & 0.081 & 0.08 & 0.084 & 0.078 \\
\hline Westmoreland & 0.03 & 0.294 & 0.24 & 0.258 & 0.252 & 0.249 & 0.252 & 0.249 & 0.237 & 0.243 & 0.24 & 0.252 & 0.234 \\
\hline St. Elizabeth & 0.04 & 0.392 & 0.32 & 0.344 & 0.336 & 0.332 & 0.336 & 0.332 & 0.316 & 0.324 & 0.32 & 0.336 & 0.312 \\
\hline Manchester & 0.06 & 0.588 & 0.48 & 0.516 & 0.504 & 0.498 & 0.504 & 0.498 & 0.474 & 0.486 & 0.48 & 0.504 & 0.468 \\
\hline Clarendon & 0.05 & 0.490 & 0.40 & 0.430 & 0.420 & 0.415 & 0.420 & 0.415 & 0.395 & 0.405 & 0.40 & 0.420 & 0.390 \\
\hline St. Catherine & 0.08 & 0.784 & 0.64 & 0.688 & 0.672 & 0.664 & 0.672 & 0.664 & 0.632 & 0.648 & 0.64 & 0.672 & 0.624 \\
\hline
\end{tabular}

Table 4: Area-Time Specific Mortality Model.

\begin{tabular}{|l|c|c|c|c|c|c|c|c|c|c|c|c|}
\hline Parish & $\mathbf{2 0 1 1}$ & $\mathbf{2 0 1 0}$ & $\mathbf{2 0 0 9}$ & $\mathbf{2 0 0 8}$ & $\mathbf{2 0 0 7}$ & $\mathbf{2 0 0 6}$ & $\mathbf{2 0 0 5}$ & $\mathbf{2 0 0 4}$ & $\mathbf{2 0 0 3}$ & $\mathbf{2 0 0 2}$ & $\mathbf{2 0 0 1}$ & Average \\
\hline Kingston and St. Andrew & 9.764 & 7.836 & 6.984 & 6.936 & 7.407 & 6.697 & 7.263 & 4.975 & 7.212 & 6.961 & 7.451 & 7.226 \\
\hline St. Thomas & 5.904 & 5.177 & 5.002 & 6.038 & 5.391 & 5.275 & 6.294 & 6.347 & 6.260 & 6.353 & 6.201 & 5.840 \\
\hline Portland & 5.194 & 5.205 & 4.275 & 4.520 & 5.212 & 4.754 & 5.525 & 6.378 & 5.545 & 6.054 & 5.773 & 5.312 \\
\hline St. Mary & 6.155 & 5.547 & 5.347 & 5.951 & 5.783 & 5.000 & 5.184 & 6.230 & 5.784 & 5.525 & 6.370 & 5.716 \\
\hline St. Ann & 6.412 & 6.274 & 5.788 & 5.286 & 5.100 & 5.837 & 6.414 & 5.148 & 5.456 & 5.974 & 6.764 & 5.859 \\
\hline Trelawny & 5.264 & 4.600 & 5.072 & 4.863 & 4.697 & 4.479 & 4.826 & 5.491 & 5.328 & 5.196 & 6.090 & 5.082 \\
\hline St. James & 8.381 & 7.579 & 6.451 & 6.601 & 7.158 & 7.582 & 6.525 & 5.182 & 5.604 & 6.493 & 7.834 & 6.854 \\
\hline Hanover & 4.542 & 4.690 & 3.728 & 4.399 & 4.158 & 4.153 & 4.545 & 5.915 & 4.643 & 4.323 & 5.102 & 4.563 \\
\hline Westmoreland & 6.269 & 5.700 & 4.995 & 6.185 & 5.586 & 5.248 & 5.566 & 5.400 & 5.358 & 6.108 & 6.801 & 5.747 \\
\hline St. Elizabeth & 5.993 & 5.685 & 5.129 & 5.940 & 5.832 & 5.010 & 5.666 & 6.008 & 4.662 & 5.482 & 6.182 & 5.599 \\
\hline Manchester & 7.821 & 8.257 & 6.681 & 8.143 & 7.399 & 7.923 & 7.953 & 5.948 & 7.571 & 7.693 & 7.260 & 7.514 \\
\hline Clarendon & 5.162 & 4.860 & 4.100 & 4.865 & 5.286 & 4.577 & 3.585 & 5.790 & 4.333 & 4.544 & 5.329 & 4.766 \\
\hline St. Catherine & 8.226 & 6.055 & 5.996 & 5.950 & 6.162 & 5.833 & 6.400 & 4.521 & 5.602 & 6.656 & 6.906 & 6.210 \\
\hline Area-specific Mortality Rate & $\mathbf{6 . 1 6}$ & $\mathbf{6 . 2 4}$ & $\mathbf{5 . 7 3}$ & $\mathbf{5 . 6 1}$ & $\mathbf{5 . 3 3}$ & $\mathbf{5 . 8 6}$ & $\mathbf{5 . 5 0}$ & $\mathbf{5 . 8 9}$ & $\mathbf{5 . 7 8}$ & $\mathbf{5 . 1 0}$ & $\mathbf{6 . 3 5}$ & $\mathbf{5 . 8 9}$ \\
\hline & & & & $\mathbf{5}$ &
\end{tabular}

Table 5: Area-Specific Mortality Rate Model.

period. The majority of deaths occurred in January (9.8\%), with the least being in December (7.8\%). Although on average the least number of deaths occurred in December (7.8\%); in 2011, 11\% of Jamaicans died in December compared to 8\% in Feburary and 9\% in August as well as April-to-June. Furthermore, mortality is relatively consistent in February and August, with January showing the greatest fluctuation in incidence rate. In fact, on average, $8.3 \%$ of Jamaicans die each month. The incidence rate of mortality in January reads: $8 \% \leq$ Mortality $\leq 12 \%$.
Table 4 presents the Area-Time Specific Mortality Model of Jamaica, for Area of Death and Time of Death. The last column (total in \%) indicates the total percentage of deaths of Jamaicans in the parish of death. Each time of death has a proportion (i.e. $i=0.098$ for January to 0.078 for December). Of the $20 \%$ of deaths recorded in Kingston and Saint Andrew for the 12-year period (2000-2011), 1.96\% occurred in January, $1.72 \%$ in March to $1.56 \%$ in December.

Table 5 presents information on the Area-Specific Mortality Rate 


\begin{tabular}{|c|c|c|c|c|c|c|c|c|c|c|c|c|}
\hline Parish & 2011 & 2010 & 2009 & 2008 & 2007 & 2006 & 2005 & 2004 & 2003 & 2002 & 2001 & 2000 \\
\hline Kingston and St. Andrew & 0.008 & 0.007 & 0.006 & 0.007 & 0.007 & 0.007 & 0.007 & 0.005 & 0.007 & 0.007 & 0.007 & \\
\hline St. Thomas & 0.006 & 0.005 & 0.005 & 0.006 & 0.005 & 0.005 & 0.006 & 0.006 & 0.006 & 0.006 & 0.006 & \\
\hline Portland & 0.005 & 0.005 & 0.004 & 0.005 & 0.005 & 0.005 & 0.006 & 0.006 & 0.006 & 0.006 & 0.006 & \\
\hline St. Mary & 0.006 & 0.006 & 0.005 & 0.006 & 0.006 & 0.005 & 0.005 & 0.006 & 0.006 & 0.006 & 0.006 & \\
\hline St. Ann & 0.006 & 0.006 & 0.006 & 0.005 & 0.005 & 0.006 & 0.006 & 0.005 & 0.005 & 0.006 & 0.007 & \\
\hline Trelawny & 0.005 & 0.005 & 0.005 & 0.005 & 0.005 & 0.004 & 0.005 & 0.005 & 0.005 & 0.005 & 0.006 & \\
\hline St. James & 0.008 & 0.008 & 0.006 & 0.007 & 0.007 & 0.008 & 0.007 & 0.005 & 0.006 & 0.006 & 0.008 & \\
\hline Hanover & 0.005 & 0.003 & 0.004 & 0.004 & 0.004 & 0.004 & 0.005 & 0.003 & 0.005 & 0.004 & 0.005 & \\
\hline Westmoreland & 0.006 & 0.006 & 0.005 & 0.006 & 0.006 & 0.005 & 0.006 & 0.005 & 0.005 & 0.006 & 0.007 & \\
\hline St. Elizabeth & 0.006 & 0.006 & 0.005 & 0.006 & 0.006 & 0.005 & 0.006 & 0.006 & 0.005 & 0.005 & 0.006 & \\
\hline Manchester & 0.008 & 0.008 & 0.007 & 0.008 & 0.007 & 0.008 & 0.008 & 0.006 & 0.008 & 0.008 & 0.007 & \\
\hline Clarendon & 0.005 & 0.005 & 0.004 & 0.005 & 0.005 & 0.005 & 0.004 & 0.006 & 0.004 & 0.005 & 0.005 & \\
\hline St. Catherine & 0.007 & 0.006 & 0.005 & 0.006 & 0.004 & 0.006 & 0.005 & 0.005 & 0.006 & 0.054 & 0.005 & \\
\hline Annual Prob. Of death & 0.006 & 0.008 & 0.006 & 0.006 & 0.006 & 0.006 & 0.006 & 0.005 & 0.006 & 0.006 & 0.006 & 0.006 \\
\hline
\end{tabular}

Table 6: Area-Specific Probability of Death Model.

\begin{tabular}{|c|c|c|c|c|c|c|c|}
\hline \multirow[t]{2}{*}{ Details } & \multicolumn{2}{|c|}{ Unstandardized Coefficients } & \multirow{2}{*}{$\begin{array}{c}\text { Standardized } \\
\text { Coefficients } \\
\text { Beta }\end{array}$} & \multirow[t]{2}{*}{ t-statistic } & \multirow[t]{2}{*}{$P$ value } & \multirow{2}{*}{$\begin{array}{c}95.0 \% \text { Confidence } \\
\text { Interval }\end{array}$} & \multirow[t]{2}{*}{$\mathbf{R}^{2}$} \\
\hline & B & Std. Error & & & & & \\
\hline Constant & -24785.427 & 9424.71 & & -2.630 & 0.025 & $-45784.98--3785.87$ & \\
\hline Urbanization & 70.183 & 10.93 & 1.367 & 6.419 & $<0.0001$ & $45.82-94.55$ & 0.799 (or $79.9 \%$ ) \\
\hline Sex ratio & 233.591 & 90.22 & .551 & 2.589 & 0.027 & $32.58-434.61$ & 0.081 (or $8.1 \%)$ \\
\hline
\end{tabular}

Dependent variable: Mortality

F statistic $[2,10]=36.65, P<0.0001$

$\mathrm{R}^{2}=0.880$

Durbin Watson $=2.348$

Table 7: Mortality, Urbanization and Sex Ratio Model: 2011

Model for Jamaica. The general Area-specific Mortality Rate for Jamaica between 1999 and 2012 is expressed in a mathematical notation: 5.10 $\leq$ ASMR $\leq 6.35$. This means that mortality rate in Jamaica lies between 5.10 per 1000 to 6.35 per 1000 or that 5 people die in every 1000 of the mid-year population. In addition, Saint James, Kingston and Saint Andrew, and Manchester are parishes with the greatest rates of mortality in Jamaica, with Hanover having the least mortality rate than other areas.

Table 6 shows the Area-Specific Probability of Death Model. The annual probability of mortality in Jamaica, for the studied period, is $0.005 \leq \mathrm{p}_{\mathrm{x}} \leq 0.008$. This denotes that probability of living through each year in Jamaica, for the studied period, lies between 0.992 and 0.995 . Furthermore, the Area-Specific Probability Mortality for Kingston and Saint Andrew reads: $0.005 \leq p_{x} \leq 0.008$. Nevertheless, the probability of dying in Kingston and Saint Andrew is generally greater than that of Jamaica, which is equally the case in Saint James (i.e., $0.005 \leq p_{x}$ $\leq 0.008$ ), Manchester (i.e., $0.006 \leq p_{x} \leq 0.008$ ), with the probability of dying being the least in Hanover $\left(0.003 \leq \mathrm{p}_{\mathrm{x}} \leq 0.005\right)$.

Table 7 presents information that will allow us to answer two hypotheses

$\mathrm{H}_{0} 1$ (i.e., null hypothesis one): Mortality in Jamaica $\neq f$ (Urbanization, Sex-ratio)

$\mathrm{H}_{\mathrm{o}} 2$ (i.e., null hypothesis two): Urbanization contributes less to mortality than the sex-ratio

Based on the information in Table 6, with the $p$ values of less than $5 \%$ for urbanization (i.e., $\mathrm{p}<0.0001$ ) and sex-ratio (i.e. $\mathrm{p}=0.027$ ) this rejects the null hypothesis that those variables are not factors of mortality in Jamaica. In fact, urbanization and the sex-ratio explain $88 \%$ of the variability in mortality in Jamaica, with urbanization explaining $79.9 \%$ of the variability and the sex-ratio contributing the remaining

\begin{tabular}{|l|l|c|c|c|}
\hline \multicolumn{2}{|l|}{} & Mortality & Urbanization & Sex ratio \\
\hline Pearson Correlation & Mortality & 1.000 & 0.894 & -0.621 \\
\cline { 2 - 5 } & Urbanization & 0.894 & 1.000 & -0.857 \\
\cline { 2 - 5 } & Sex ratio & -0.621 & -0.857 & 1.000 \\
\hline \multirow{3}{*}{ Sig. (1-tailed) } & Mortality &. & 0.000 & 0.012 \\
\cline { 2 - 5 } & Urbanization & 0.000 &. & 0.000 \\
\cline { 2 - 5 } & Sex ratio & 0.012 & 0.000 &. \\
\hline $\mathrm{N}$ & & 13 & 13 & 13 \\
\hline
\end{tabular}

Table 8: Correlation matrix, 2011.

$8.1 \%$. Further examination of direction of each factor is presented in Table 7 (See also, Eqn. [1]):

\section{Mortality function $=\mathrm{A}+\alpha \mathrm{U}+\beta \mathrm{S}(1)$}

Where $\mathrm{A}$ is a constant, $\mathrm{U}$ is urbanization rate and $\mathrm{S}$ denotes the sex-ratio, parameters $\alpha$ and $\beta>0$

H 3: (i.e., null hypothesis three): An inverse correlation exists between urbanization and the sex-ratio

Table 8 presents information on correlations between pairs of factors: mortality and urbanization; mortality and sex ratio; sexratio and urbanization. Hence, we fail to reject the null hypothesis. A strong positive statistical correlation exists between mortality and urbanization (Pearson's correlation coefficient $=0.894 ; \mathrm{P}<0.0001$ ) and an indirect association between mortality and sex-ratio (Pearson's correlation coefficient $=-0.621, \quad \mathrm{P}=0.012)$. A negative statistical association exists between urbanization and the sex ratio (Pearson's correlation coefficient $=-0.857, \mathrm{P}<0.0001)$. This denotes that the more an area in Jamaica is urbanized, the lower the sex ratio (i.e., number of males per 100 females) and vice versa.

Age-specific probability of mortality curve: $\mathrm{H}_{\mathrm{o}} 4$ (i.e., null 
hypothesis four): The probability of death for age is not an exponential function.

Figure 1 depicts an exponential function of the probability of age for male and female, Jamaica. The probability of age curve rejects the null hypothesis as death increases exponentially with advanced ages, expressed as:

$\mathrm{h}(\mathrm{x})=\alpha \mathrm{e}^{\beta \mathrm{x}}$ where $\alpha, \beta>0, x \in R^{+}$and $\mathrm{h}(\mathrm{x})$ is the probability of dying at age interval $\mathrm{x}$ over the range $0-75+$ years.

The age-dependent component of mortality as forwarded by Gompertz is best concurred with this study at ages $40+$ years in Jamaica as there is an exponential rise in mortality after 40 years. In fact, ages 4 to 40 years (i.e., 4 years $\leq$ age $\leq 40$ years) sees fluctuations in mortality rates (probability of death) and then a rise $40+$ years. Although, an exponential rise in mortality rates occurred between ages 14 and 25 years in the period of mortality fluctuations. This indicates that the exponential rise in mortality rates is not consistent over the entire age cohort as proposed by Benjamin Gompertz in 1825 [3]. The values for the probabilities of death for age and by the sexes are computed and presented in the Annex as well as graphically displayed in Figure 1.

$\mathrm{H}_{\mathrm{o}} 5$ (i.e., null hypothesis five): The probability of death for age is

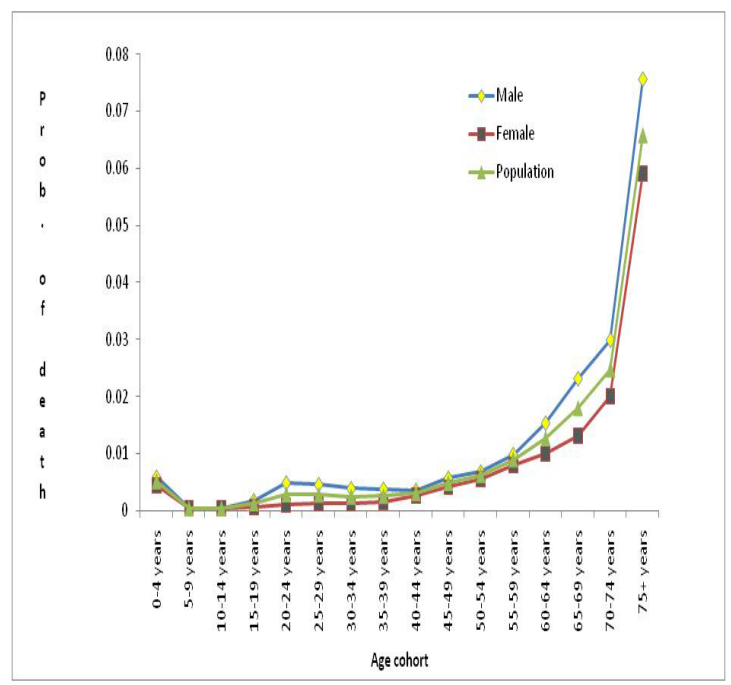

Figure 1: Probability of death of age for the sexes, $0-75+$ years.

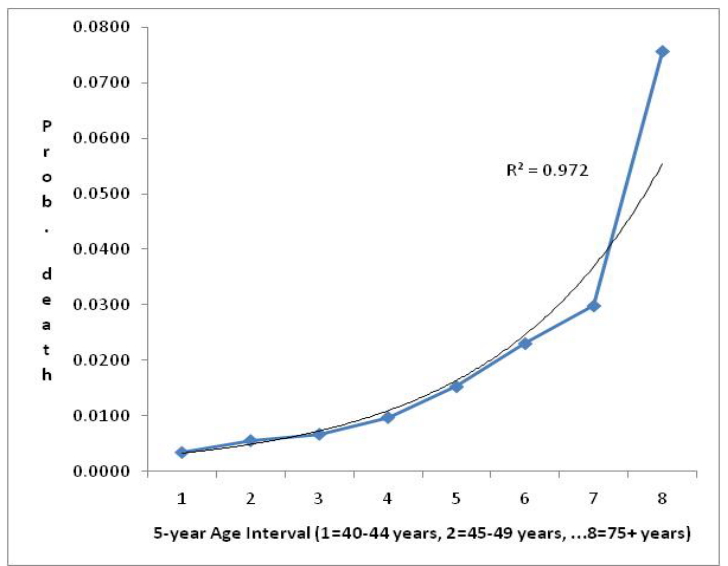

Figure 2: Probability of death from 40-75+ years old.

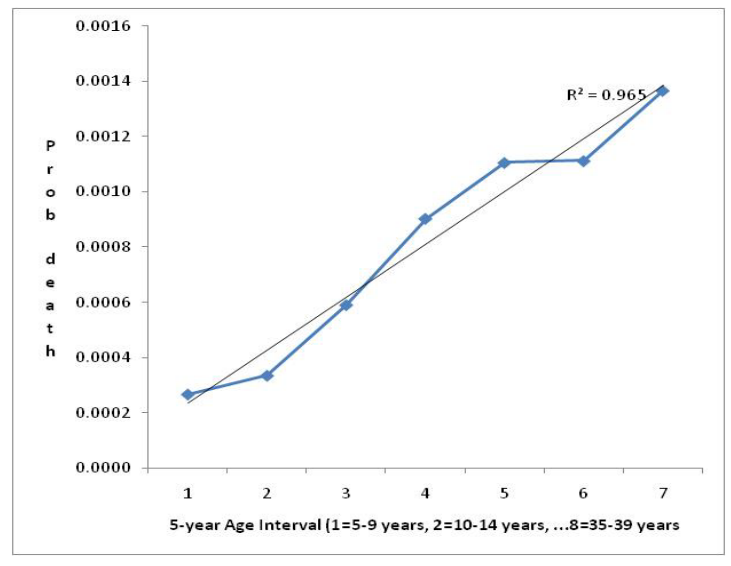

Figure 3: Probability of death from 5-39 years old.

the same slope over the lifecourse.

$\mathrm{H}_{\mathrm{o}} 5$ (i.e., null hypothesis five): The probability of death is the same slope over the lifecourse.

Figures 2 and 3 depicts different slope between 5-39 years and 40-75+ years. In fact, an exponential function of the probability of age is depicted between for 40-75+ years and a straight line for ages 5-39 years old Jamaicans. The probability of age curves rejects the null hypothesis that death increases exponentially with over the lifecourse. The exponential increases in mortality occurs from $40+$ years as well as advanced ages, expressed in Figure 2 (or equation $\mathrm{h}(\mathrm{x})$ ):

$\mathrm{h}(\mathrm{x})=\alpha \mathrm{e}^{\beta \mathrm{x}}$ where $\alpha, \beta>0, x \in R^{+}$and $\mathrm{h}(\mathrm{x})$ is the probability of dying at age interval $\mathrm{x}$ over the range $40-75+$ years.

The probability of death for Jamaicans ages 5-39 years is best expressed by a straight line (Figure 3 ) and $t(x)$ ):

$t(x)=\alpha+\beta x$ where $\alpha, \beta>0$, $x$ is 5 -year age cohort, and $t(x)$ is the probability of dying at age interval $x$, ages 5-39 years.

$\mathrm{H}_{\mathrm{o}} 6$ (i.e., null hypothesis six): Urbanization constantly increases the rate of death in geographical areas.

Figure 4 depicts two functions each expressing the rate of change in urbanization and how this affect the proportion of deaths in each parish. Based on the explanatory power (i.e., $\mathrm{R}^{2}$ ), the straight line is a better fit of the data than the exponential function. Hence, we failed to reject the null hypothesis as propotion of deaths in each geographic parish is explained by a constant rate of change in urbanization. In addition to the aforementioned issues, when the rate of urbanization is $35 \%$ or greater, the proportion of deaths is at least $5 \%$ and urbanization beyond $90 \%$ is associated with a proportion of mortality of $20 \%$ (Figure 4 ).

\section{Limitations}

Mortality comprises of murder and non-murder components. Although the non-murder mortality figures used are numbers that are published nationally, due to calculation errors along with institutional coordination issues of data collection agencies, some of the data presented may either be a little more or a little less than expected. The non-murder component of mortality is the larger proportion, and this larger component is more affected by the errors and issues presented earlier. 


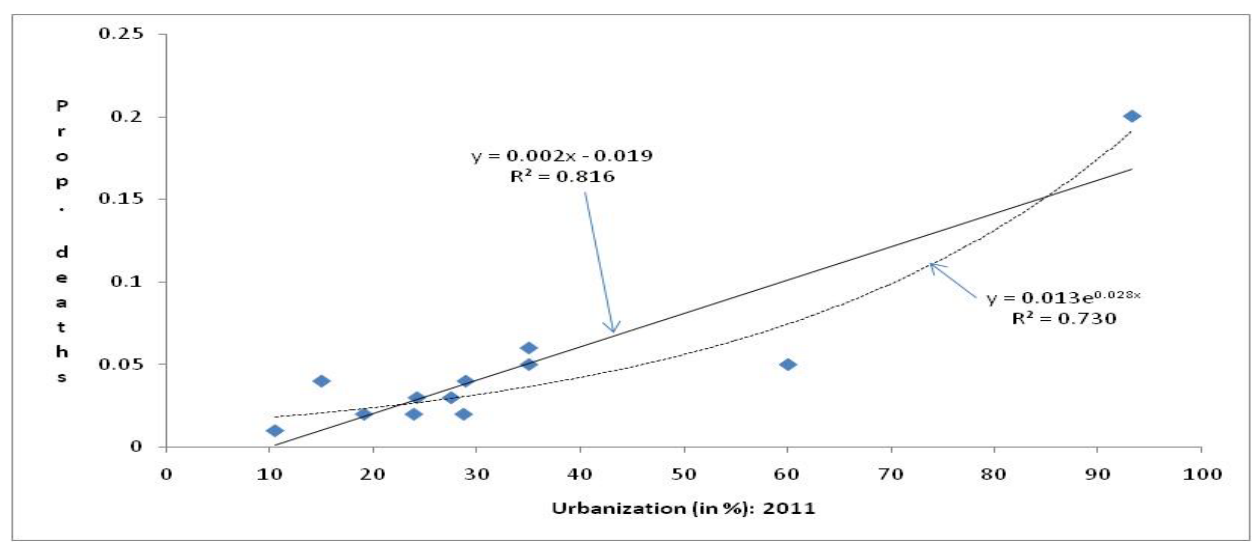

Figure 4: Curve for proportion of death for each parish by rate of urbanization for each respective parish, 2011.

\section{Discussion}

The mortality discourse commenced as early as the seventeenth century with John Graunt [1] and this has increased with new tenets [26]. Unlike other studies in the mortality discourse, this research covers area-time specific mortality models, urbanization and the sex ratio explain mortality as well as the potency of each factor on mortality. Some of the findings that emerged from the current study are that the average probability of death in Jamaica for studied period is 0.006 ; the average mortality rate is 614 per 100,000 ; average murder rate is 50 per 100,000 . On average murder accounts for $8 \%$ of average mortality, and the probability of mortality changes over the lifecourse. The majority of mortality in Jamaica occurred in Kingston and Saint Andrew (20\% of total deaths) followed by Saint Catherine (8\%), Manchester (6\%) and then Saint James (5\%). As it relates to time mortality rate, $9.8 \%$ of deaths occurred in January; $8.6 \%$ in March and $8.4 \%$ in April, June and November, with December having the least number of deaths $(7.8 \%)$. Furthermore, urbanization accounts for $79.9 \%$ of the variability in mortality and this factor directly influences mortality. In addition to the aforementioned findings, areas with more females are more likely to have greater mortality.

The issue of urbanization influencing mortality is already established in the literature [27-31], with this research concurring with past empirical findings. However, this study confirms that urbanized areas are more likely to have more deaths and this is equally the case if the area has more females than males. The parishes with the majority of deaths in Jamaica (Saint Andrew and Kingston; Saint James; Saint Catherine and Manchester), 39\% of total mortality, have sex-ratios that are lower than 100 per 100 females, indicating that more females reside therein than males with the exception of Manchester. The rate of urbanization in Kingston (100\%) and Saint Andrew (86.5\%) is 93.5\%, a sex ratio of 96.7 males per 100 females and $20 \%$ mortality occuring in these parishes, of which $1.96 \%$ of the deaths occur in January. On the contrary, Hanover has the least urbanization rate in Jamaica (10.5\%), a sex-ratio of 101.7 males per 100 females and the lowest proportion of deaths (1\%) compared to highly urbanized and proportion of deaths like Kingston and Saint Andrew, Saint James (urbanization rate $=60 \%$ ). It is urbanization's influence on mortality that is critical in the mortality discourse than gender and urbanization plays a dominant role in the death profile of Jamaicans. There has been a rapid urbanization of many rural areas in Jamaica as in 1970 the rate of urbanization was $40.6 \%$ and in 2011 it stood at $53.9 \%$ [25], and this is associated with overcrowding, urban sprawl, poor housing and living conditions, poor sanitary convenience and other social amenties which are explaining the increasing rise in mortality in Jamaica and by extension low-tomiddle income nations.

Another new finding emerging from this study is the inverse correlation between the sex-ratio and urbanization, which indicates that on average areas in Jamaica with a greater degree of urbanization have a greater likeliness of having more females residing therein. Those findings can be contextualized with past research. A study by Bourne et al. [7] found that the mortality rate of Jamaicans $60+$ years old is 58.64 per 100 of the mid-year population and that this was greater for females than for males. Another study by Bourne et al. [32] revealed that in $2008,49.9 \%$ of mortality were related to chronic non-communicale diseases (male, $44.4 \%$; female, $57.1 \%$ ) as well as that ageing is associated with ageing-related diseases like chronic conditions (i.e, cardiovascular diseases, diabetes, cancers, arthritis). Those studies provided significant insights into the mortality rates of the current work, the feminization of deaths and also concurs with the current findings that deaths are feminized phenomenon in Jamaica. We can deduce from this research and those of the literature that urbanization, feminization, ageing at older ages and time of the year are reducing the life expectancy of Jamaicans, and that murder is secondary to communicable diseases as well as urbanization. There is a clear reality added by this study that mortality is shrouded by urbanization and masculinity, and that probability of death has being relatively consistent over the last 12 years in Jamaica, with murder playing a small role in the mortality discourse.

The life expectancy of Jamaican females is greater than that of males [24], which offers an insight into the survivability of the sexes and account for the gender-mortality differential (i.e. greater probability of deaths of females than males), indicating that former have a different mortality profile than the latter, which concurs with the literature [3336]. Although mortality is a gendered phenomenon (i.e., occurring mostly among females) in Jamaica like in many nations, this research shows that urbanization is changing the mortality structure more than other issues in the mortality discourse. The difference between this work and the literature is that urbanization is accounting for majority of the deaths in Jamaica which is not the case in rural Australia [37-41]. Furthermore, another difference lies in the direction of urbanization and mortality between this study and the literature. In the literature there is an inverse correlation between mortality and urbanization [4247], which is not the case in Jamaica. In fact, there is a dominance of urbanization in explaining the rise in mortality in Jamaica, which is not the case in the literature. A group of scholars opined that "Thus urban mortality decline by itself cannot drive urbanization" [47], which is not the case in Jamaica as urbanization accounts for almost $80 \%$ of 
the variability in mortality. Bandyopadhyay and Green [47] offered an explanation for what is happening in Jamaica as it relates to the urbanization-mortality paradigm by suggesting that "Our preliminary results suggest that mortality decline causes urbanization through the creation of new cities rather than promoting urban growth in alreadyextant cities". Their perspective is profound in explaining what is occurring in Jamaica as the increases in mortality are owing to the expansion of new urban centres. This means that urbanization of new centres indicate 1) overcrowding, 2) congestion, 3) increase pollution, 4) reduced leisure time, and 5) those account for the greater degree of mortality occurring in Jamaica not due to the expansion of already urban areas. Such a proposition is encapsulated in the fact that the urban centre with the greatest proportion of mortality in Jamaica has a rate of urbanization of over $90 \%$ (i.e., Kingston and Saint Catherine) and this has been increasing at a constant over the past two decades, with the rate of urbanization in some parishes increasing at a geometric rate and having greater mortality than those with constant urbanization like Saint Catherine, Saint James, and Manchester. However, we do not concur with Bandyopadhyay and Green [47] that there is a causal link between urbanization and mortality even though there is evidence that the relationship is a very strong one. Another disagreement is with the direction of association, we found positive and Bandyopadhyay and Green [47] research turned out to be an inverse association.

In addition, the urbanization-mortality phenomenon as well as the sex-ratio mortality phenomenon is arithmetic law unlike the exponential law between the probability of mortality and age which concurs with Benjamin Gompertz's work on the law of mortality [3]. In fact, this work disagrees with the theory developed by that mortality rate increases more slowly at advanced ages [48] as well as the theory advanced by Gompertz [3] that mortality increases exponentially over the lifecourse. The rate of change of mortality of Jamaicans ages 5-39 years increases at a constant rate, while the rate of change of death at advanced ages, 40+ years, increases at an increasing rate (i.e., exponential rate). We can deduced from the current findings and those of the literature that lifestyle practices of the urban peoples are retarding the life expectancy of people in urban centres and resulting in the increases in deaths.

\section{Conclusion}

The results presented herein speaks to the dominance of urbanization in the mortality discourse and that time as well as the sexratio offers some insights into changes in mortality. Outside of those issues, time and the age cohorts are crucial in mortality discourse and at advanced ages the rate of mortality increases at an increasing rate compared to the constant rate at ages 5-39 years. Clearly, urbanization is an epidemic like chronic non-communicable diseases and practices of people in urban areas explain the risk factors associated with many diseases and the resulting mortality in developed and developing societies.

\section{References}

1. Graunt J (1939) Natural and political observations made upon the Bills of Mortality; 1662. Willcox WF ed., Johns Hopkins University Press, Baltimore.

2. Makeham WM (1860) On the Law of Mortality and the Construction of Annuity Tables. J. Inst. Actuaries and Assur. Mag 8: 301-310.

3. Gompertz B (1825) On the Nature of the Function Expressive of the Law of Human Mortality, and on a New Mode of Determining the Value of Life Contingencies. Philosophical Transactions of the Royal Society 115: 513-585.

4. Strehler BL, Mildvan AS (1960) General Theory of Mortality and Aging. Science 132: 14-21.
5. Gavrilov LA, Gavrilova NS, Nosov VN (1983) Human life span stopped increasing: Why? Gerontology 29: 176-180.

6. Gavrilova NS, Gavrilov LA (2011) Ageing and Longevity: Mortality Laws and Mortality Forecasts for Ageing Populations. In: Stárnutí a dlouhovekost: Zákony a prognózyúmrtnosti pro stárnoucí populace. Demografie, Czech 53: 109-128.

7. Bourne PA, Solan I, Sharpe-Pryce C, Campbell-Smith J, Francis C (2014) Human Ageing, Mortality and the Role of Macroeconomics Variables in Determining Death at Older Ages. Epidemiol 4: 144.

8. Bourne PA, McGrowder DA, Crawford TV (2009) Decomposing Mortality Rates and Examining Health Status of the Elderly in Jamaica. The Open Geriatric Medicine Journal 2: 34-44.

9. Bourne PA (2009) Impact of poverty, not seeking medical care, unemployment inflation, self-reported illness, health insurance on mortality in Jamaica. North American Journal of Medical Sciences 1: 99-109.

10. Bourne PA (2012) Births, economic growth, mortality and murder in a developing country. Health $4: 46-55$.

11. March C, Bourne PA (2011) The Influence of Macroeconomic Factors on Murders in Jamaica: Should the Police Be Cautious in Interpreting the Murder Statistics? Asian Journal of Business Management 3: 257-277

12. Keyfitz N (1977) Introduction to the mathematics of populaiton with revisions Massachusetts: Addison-Wesley Publishing Company.

13. Ogborn MA (1953) On the nature of the function expressive of the law of human mortality. JIA, 79: 0170-0212.

14. Rowland DT (2003) Demographic methods and concepts. Oxford University Press, Oxford.

15. Preston SH, Heuveline P, Guillot M (2001) Demography: Measuring and modelling population processes. Massachusetts: Blackwell Publishers.

16. Newell C (1988) Methods and models in demography. The Guilford Press, New York.

17. Echouffo-Tcheugui JB, Kengne AP (2011) Chronic non-communicable diseases in Cameroon-burden, determinants and current policies. Globalization and Health 7: 44

18. Mathers CD, Boerma T, Ma Fat D (2009) Global and regional causes of death. Br Med Bull 92: 7-32.

19. Hospedales CJ, Samuels TA, Cummings R, Gollop G, Greene E (2011) Raising the priority of chronic noncommunicable diseases in the Caribbean. Rev Panam Salud Publica 30: 393-400.

20. Abdulkadri AO, Cunningham-Myrie C, Forrester T (2009) Economic burden of diabetes and hypertension in CARICOM states. Soc Econ Stud 58: 175-97.

21. World Health Organization (2005) Preventing Chronic Diseases a vital investment. WHO, Geneva.

22. World Health Organization. (2008) Global Burden of Disease 2004 Update WHO, Geneva.

23. Planning Institute of Jamaica (1989-2013) Economic and Social Survey of Jamaica, 1988-2012. PIOJ, Kingston.

24. Statistical Institute of Jamaica (STATIN) (1999-2013) Demographic statistics, 1999-2012. STATIN, Kingston.

25. Statistical Institute of Jamaica (STATIN) (2012) 2011 Census of Population and Housing report. STATIN, Kingston.

26. Statistical Department, Jamaica Constabulary Force (JCF) (2000-2011) Murder statistics, 2000-2011. JCF, Kingston.

27. Smith SM, Mensah G (2003) Population aging and implications for epidemic cardiovascular disease in Sub-Saharan Africa. Ethn Dis 13: S77-S80.

28. Bourne PA, Francis C, Sharpe-Pryce C, Davis AH, Solan I (2014) Diabetes, Hypertension, Arthritis and Other Chronic Non-communicable Diseases in an English-speaking Caribbean Nation: A Health Perspective. J Endocrinol Diab 1: 12 .

29. Niakara A, Nebie LV, Zagre NM, Ouedraogo NA, Megnigbeto AC (2003) Knowledge of an urban population about arterial hypertension: prospective study carried out in Ouagadougou, Burkina Faso. Bull Soc Pathol Exot 96: 219-222. 
Citation: Bourne PA, Hudson-Davis A, Sharpe-Pryce C, Clarke J, Solan I, et al. (2015) Mathematical Mortality Models and Modeling Urbanization's Influence on Deaths in Jamaica. Arts Social Sci J 6: 102. doi:10.4172/2151-6200.1000102

30. World Health Organization (2012) Good Health Adds Life to Years: Global Brief for World Health Day 2012. WHO, Geneva.

31. Yamada T, Chen CC, Chiu IM, Rizvi SW (2013) Non-Communicable Diseases in Developing Countries: Causes and Health Policy/Program Assessments. J Trop Dis 1: 117.

32. Bourne PA, Francis C, Sharpe-Pryce C, Hudson-Davis A, Solan I, et al. (2014) Epidemic of non-communicable diseases in Jamaica: Monsters awoken from lifestyle. Oalib 1: 1-16.

33. Draper G, Turrell G, Oldenburg B (2004) Health Inequalities in Australia: Mortality. Queensland University of Technology and the Australian Institute of Health and Welfare, Canberra.

34. Annandale E, Hunt K (2000) Gender inequalities in health. Open University Press, Buckingham.

35. Cameron E, Bernardes J (1998) Gender and disadvantage in health: men's health for a change. In: Bartley M, Blane D, Davey SG (Eds). The sociology of health inequalities. Blackwell, Oxford 115-34.

36. Hart N (1989) Sex, gender and survival: inequalities of life chances between European men and women. In: J Fox (Ed.) Health inequalities in European Countries. Gower Publishing, Aldershot 109-141.

37. Mathers C (1994) Health differential among adult Australians aged 25-64 years. Australian Institute of Health and Welfare, AGPS, Canberra.

38. Mathers C (1994) Health differentials among older Australians. Australian Institute of Health and Welfare: Health Monitoring Series No. 2. AGPS, Canberra.
39. Mathers C (1995) Health differentials among Australian children. Australian Institute of Health and Welfare: Health Monitoring Series No 3. Canberra: AGPS.

40. Mathers C (1996) Health differentials among young Australian adults. Australian Institute of Health and Welfare: Health Monitoring Series No. 4 AGPS, Canberra.

41. Mathers C, Vos T, Stevenson C (1999) The burden of disease and injury in Australia. AlHW Cat. No. PHE 17. AlHW, Canberra.

42. Dyson T (2011) The Role of the Demographic Transition in the Process of Urbanization. Population and Development Review 37: 35-54.

43. Haines MR (2001) The Urban Mortality Transition in the United States, 18001940. NBER Historical Working Paper No.134

44. Lynch KA (2003) Individuals, Families and Communities in Europe, 1200-1800 Cambridge University Press, Cambridge.

45. Lees LH, Hohenberg PM (1989) Urban Decline and Regional Economies: Brabant, Castile, and Lombardy, 1550-1750. Comparative Studies in Society and History 31: 439-461.

46. Wrigley EA (1985). Urban Growth and Agricultural Change: England and the Continent in the Early Modern Period. Journal of Interdisciplinary History 15 683-728.

47. Bandyopadhyay S, Green E (2013) Urbanization and mortality decline Population Seminar Series and Oxford University (CSAE).

48. Gavrilov LA, Gavrilova NS (1991) The Biology of Life Span: A Quantitative Approach. Harwood Academic Publisher, New York 